\section{Cureus}

\title{
Gastrointestinal Side Effects of Antiarrhythmic Medications: A Review of Current Literature
}

\author{
Waseem Amjad ${ }^{1}$, Waqas Qureshi ${ }^{2}$, Ali Farooq ${ }^{3}$, Umair Sohail ${ }^{4}$, Salma Khatoon ${ }^{1}$, Sarah \\ Pervaiz ${ }^{5}$, Pratyusha Narra ${ }^{6}$, Syeda M. Hasan ${ }^{5}$, Farman Ali ${ }^{7}$, Aman Ullah ${ }^{8}$, Steven Guttmann \\ 9
}

1. Forest Hills Hospital, Northshore-Long Island Jewish Health System 2. Internal Medicine, Wake Forest Baptist Hospital 3. Internal Medicine, West Virginia University - Charleston Division 4. Gastroenterology and Hepatology, East Texas Medical Center 5. Internal Medicine, Northwell - Long Island Jewish Forest Hills Hospital 6. Medicine, Northwell - Long Island Jewish Forest Hills Hospital 7. Medicine, St.john Hospital and Medical Center, Detroit 8. Internal Medicine, St Joseph Mercy Oakland Hospital 9. Digestive Diseases, Northwell - Long Island Jewish Forest Hills Hospital

$\square$ Corresponding author: Ali Farooq, dr.aliumair786@gmail.com

Disclosures can be found in Additional Information at the end of the article

\section{Abstract}

Antiarrhythmic drugs are commonly prescribed cardiac drugs. Due to their receptor mimicry with several of the gastrointestinal tract receptors, they can frequently lead to gastrointestinal side effects. These side effects are the most common reasons for discontinuation of these drugs by the patients. Knowledge of these side effects is important for clinicians that manage antiarrhythmic drugs. This review focuses on the gastrointestinal side effects of these drugs and provides a detailed up-to-date literature review of the side effects of these drugs. The review provides case reports reported in the literature as well as possible mechanisms that lead to gastrointestinal side effects.

Categories: Cardiology, Internal Medicine, Gastroenterology

Keywords: antiarrhythmic drugs, cardiac drugs, cardiac pharmacology, gastrointestinal side effects, drug side effects

\section{Introduction And Background}

Antiarrhythmics are commonly prescribed drugs and have a narrow therapeutic window. These medications mainly affect the ion channel in the cardiac cell membrane. They are proarrhythmogenic and can also cause systemic side effects including gastrointestinal side effects. Antiarrhythmic drugs have sometimes been discontinued because of these side effects. For example, amiodarone is known for pro-arrhythmogenic side effects but there are instances where the drug is stopped because of liver toxicity. Based on the Vaughan Williams classification of antiarrhythmic drugs, they are classified into four classes depending on the mechanism of action (Table 1) [1]. Class 1 is further classified into a, b, and c. Antiarrhythmics are prescribed based on an individualized approach, not following the Vaughan classification. They are either used as a single drug or in combination with multiple drugs. Some of the antiarrhythmics have more than one class action; for example, amiodarone has all four class effects and sotalol has class 2 and 3 effects. As most antiarrhythmics are metabolized and eliminated by the liver, chronic use or overdose of these drugs can lead to hepatotoxicity. 


\section{Cureus}

\begin{tabular}{|c|c|c|}
\hline Classes & Membrane Effect & Drugs \\
\hline Class 1a & $\begin{array}{l}\text { Sodium channel block; intermediate kinetics, and } \\
\text { potassium channel block }\end{array}$ & $\begin{array}{l}\text { Quinidine, procainamide hydrochloride, } \\
\text { disopyramide }\end{array}$ \\
\hline Class $1 b$ & Sodium channel block; rapid kinetics & $\begin{array}{l}\text { Lidocaine, tocainide, mexiletine } \\
\text { hydrochloride, phenytoin }\end{array}$ \\
\hline Class 1c & Sodium channel block with slow kinetics & Flecainide and propafenone \\
\hline Class 2 & Beta-receptor blocker & $\begin{array}{l}\text { Propranolol, metoprolol, esmolol, } \\
\text { acebutolol, atenolol }\end{array}$ \\
\hline Class 3 & $\begin{array}{l}\text { Potassium channel blocker, slow sodium channel } \\
\text { facilitation }\end{array}$ & $\begin{array}{l}\text { Procainamide, sotalol, dronedarone, } \\
\text { dofetilide }\end{array}$ \\
\hline Class 4 & Calcium channel blocker & Verapamil and diltiazem \\
\hline Digitalis & Sodium potassium AlPase inhibition & Digoxin, digitoxın \\
\hline Adenosine & $\begin{array}{l}\text { Inhibit cyclic adenosine monophosphate (cAMP) } \\
\text { mediated calcium influx }\end{array}$ & Adenosine \\
\hline
\end{tabular}

\section{TABLE 1: Classification of Antiarrhythmic Medications}

Modified from Kowey, et al. [1]

\section{Review}

\section{Class 1a}

Class 1a drugs include quinidine, disopyramide, and procainamide.

Quinidine

Quinidine is an optical isomer of quinine and is derived from the bark of cinchona. Quinine is used for the treatment of parasitic infections, such as malaria. Quinidine is an older drug and not used frequently because of the development of newer antiarrhythmic drugs.

Studies have shown that quinidine causes hepatotoxicity in $2 \%$ to $2.2 \%$ population. Cases presented in the literature are mostly of granulomatous hepatitis (Table 2) [2]. Clinical presentation of hepatitis, such as fever, rash, thrombocytopenia, reversibility on discontinuation of the drug, and reappearance after rechallenge, explains quinidine hepatitis as a hypersensitivity reaction. When hepatotoxicity develops, treatment is discontinuation of the medication. 


\section{Cureus}

\begin{tabular}{|c|c|c|c|c|c|}
\hline \multirow{2}{*}{ References } & \multirow{2}{*}{$\begin{array}{l}\text { Age } \\
\text { (Years)/ } \\
\text { Sex }\end{array}$} & \multirow{2}{*}{ Symptoms, signs and labs } & \multirow{2}{*}{$\begin{array}{l}\text { Duration } \\
\text { of Drug } \\
\text { Use }\end{array}$} & \multicolumn{2}{|l|}{ Outcome } \\
\hline & & & & & Repeat Exposure \\
\hline $\begin{array}{l}\text { Guharoy, et } \\
\text { al. [3] }\end{array}$ & 62/Male & $\begin{array}{l}\text { Diarrhea, nausea, fever, } \\
\text { palpitations, } \\
\text { elevated aspartate } \\
\text { aminotransferase, and } \\
\text { alanine aminotransferase }\end{array}$ & $\begin{array}{l}\text { Two } \\
\text { weeks }\end{array}$ & $\begin{array}{l}\text { Symptoms resolved in } 42 \\
\text { hours, liver enzymes } \\
\text { started decreasing } \\
\text { gradually and normalized } \\
\text { on day } 12 .\end{array}$ & No \\
\hline $\begin{array}{l}\text { Bramlet, et } \\
\text { al. [2] }\end{array}$ & Unknown & $\begin{array}{l}\text { Fever, urticaria, and mild } \\
\text { thrombocytopenia }\end{array}$ & Unknown & $\begin{array}{l}\text { Histology showed } \\
\text { granulomatous hepatitis. } \\
\text { Symptoms resolved with } \\
\text { discontinuation of the drug. }\end{array}$ & $\begin{array}{l}\text { Symptoms } \\
\text { appeared three } \\
\text { days after } \\
\text { readministration }\end{array}$ \\
\hline $\begin{array}{l}\text { Handler, et } \\
\text { al. [4] }\end{array}$ & 72/Female & $\begin{array}{l}\text { Anorexia, weight loss, } \\
\text { elevated aspartate } \\
\text { aminotransferase, alkaline } \\
\text { phosphatase, and lactate } \\
\text { dehydrogenase }\end{array}$ & $\begin{array}{l}16 \\
\text { months }\end{array}$ & $\begin{array}{l}\text { Active hepatitis on liver } \\
\text { biopsy, liver functions } \\
\text { normalized after } \\
\text { discontinuation of the drug. }\end{array}$ & $\begin{array}{l}\text { Re-challenge } \\
\text { with the drug } \\
\text { caused elevation } \\
\text { of liver enzymes } \\
\text { and lactate } \\
\text { dehydrogenase }\end{array}$ \\
\hline $\begin{array}{l}\text { Hogan, et } \\
\text { al. [5] }\end{array}$ & 85/Male & $\begin{array}{l}\text { Jaundice and vomiting, } \\
\text { elevated aspartate } \\
\text { aminotransferase, alkaline } \\
\text { phosphatase, lactate } \\
\text { dehydrogenase, and total } \\
\text { bilirubin }\end{array}$ & 8 days & $\begin{array}{l}\text { Biopsy showed } \\
\text { centrilobular cholestasis } \\
\text { and granulomatous } \\
\text { hepatitis. Quinidine } \\
\text { stopped on day } 10 \text { and liver } \\
\text { functions started } \\
\text { improving. }\end{array}$ & No \\
\hline
\end{tabular}

TABLE 3: Summary and Comparison of a Few Cases of Quinidine-induced Hepatotoxicity

As a result of its prolonged transit time, quinidine has also been reported to cause esophagitis. On average, most cases are seen at the age of 60; esophagitis caused by quinidine can lead to strictures. The condition can be prevented by taking pills in sitting position and with plenty of water. Acid suppression with histamine H2 blockers, sucralfate, and proton pump inhibitors are commonly used but their efficacy has not been clearly established. In cases where complications like strictures and perforation develop, surgical intervention may be needed [6]. Quinidine rarely causes pill-induced gastritis; however, one case of gastric ulceration has been reported. The case was managed with discontinuation of drug and use of sucralfate and rabeprazole [7].

Disopyramide

Disopyramide has similar electrophysiological properties as quinidine with fewer gastrointestinal side effects. It is mainly used for the treatment of ventricular tachycardia.

Due to anticholinergic action, disopyramide can cause constipation and dry mouth, which can 


\section{Cureus}

be controlled by the acetylcholinesterase inhibitor, pyridostigmine. Studies show that pyridostigmine has no significant effect on antiarrhythmic properties of the drug. Although disopyramide has fewer gastrointestinal side effects, cases of hepatotoxicity have been reported, as well as hepatic ischemia secondary to cardiac failure by passive congestion. The drug has a negative ionotropic effect which can worsen heart failure. Liver functions and symptoms improved after the discontinuation of the drug, and in one case, diuretics were used to resolve congestion [8]. Rarely, disopyramide can cause cholestatic jaundice that, in most cases, appears within the first week of taking the medication. Generally, cholestatic jaundice resolves promptly on discontinuation of the drug (Table 3) [9]. A case of severe hepatocellular toxicity with disseminated intravascular coagulation was reported, which improved after discontinuation of disopyramide [10]. 


\section{Cureus}

\begin{tabular}{|c|c|c|c|c|c|}
\hline \multirow{2}{*}{ References } & \multirow{2}{*}{$\begin{array}{l}\text { Age } \\
\text { (Years)/ } \\
\text { Sex }\end{array}$} & \multirow{2}{*}{ Symptom, signs and labs } & \multirow{2}{*}{$\begin{array}{l}\text { Duration } \\
\text { of drug } \\
\text { use }\end{array}$} & \multicolumn{2}{|l|}{ Outcome } \\
\hline & & & & & Repeat Exposure \\
\hline $\begin{array}{l}\text { Scheinman, } \\
\text { et al. [8] }\end{array}$ & 62/Male & $\begin{array}{l}\text { Anxiety, dyspnea, abdomen } \\
\text { pain, elevated aspartate } \\
\text { aminotransferase, and lactate } \\
\text { dehydrogenase }\end{array}$ & One day & $\begin{array}{l}\text { Hepatic necrosis } \\
\text { with congestion } \\
\text { on biopsy, } \\
\text { disopyramide } \\
\text { was } \\
\text { discontinued } \\
\text { and liver } \\
\text { enzymes and } \\
\text { symptoms } \\
\text { improved on day } \\
\text { six. }\end{array}$ & $\begin{array}{l}\text { Disopyramide was } \\
\text { restarted but the patient } \\
\text { again had a recurrence of } \\
\text { anxiety and dyspnea, it } \\
\text { was discontinued. Liver } \\
\text { enzymes did not elevate. } \\
\text { Antiarrhythmic was } \\
\text { changed to procainamide. }\end{array}$ \\
\hline $\begin{array}{l}\text { Scheinman, } \\
\text { et al. [8] }\end{array}$ & 61/Male & $\begin{array}{l}\text { Hypotension, chest pain, 1+ } \\
\text { edema lower extremity, } \\
\text { bilateral lung bases rales, } \\
\text { hepatomegaly. Aspartate } \\
\text { aminotransferase, alanine } \\
\text { aminotransferase, and lactate } \\
\text { dehydrogenase were } \\
\text { elevated }\end{array}$ & One day & $\begin{array}{l}\text { Symptoms } \\
\text { improved with } \\
\text { diuresis and liver } \\
\text { enzymes } \\
\text { normalized. }\end{array}$ & $\begin{array}{l}\text { Nausea, dyspnea, and } \\
\text { hypotension developed } \\
\text { one day after } \\
\text { readministration of } \\
\text { disopyramide. Liver } \\
\text { enzymes peaked; the drug } \\
\text { was switched to } \\
\text { procainamide and liver } \\
\text { enzymes normalized in few } \\
\text { days. }\end{array}$ \\
\hline Doody [10] & 55/Female & $\begin{array}{l}\text { Elevated liver enzymes and } \\
\text { disseminated intravascular } \\
\text { coagulation (prolonged } \\
\text { prothrombin time, elevated } \\
\text { fibrin split products) }\end{array}$ & Unknown & $\begin{array}{l}\text { Both liver } \\
\text { enzymes and } \\
\text { liver functions } \\
\text { improved } 14 \\
\text { days after } \\
\text { discontinuation } \\
\text { of therapy. }\end{array}$ & No \\
\hline $\begin{array}{l}\text { Barkins, et } \\
\text { al. [9] }\end{array}$ & Unknown & $\begin{array}{l}\text { Jaundice and abnormal liver } \\
\text { enzymes }\end{array}$ & $\begin{array}{l}\text { One } \\
\text { week }\end{array}$ & $\begin{array}{l}\text { Prompt clinical } \\
\text { resolution on } \\
\text { discontinuation } \\
\text { of the drug. }\end{array}$ & No \\
\hline
\end{tabular}

\section{TABLE 2: Comparison of Cases of Disopyramide-induced Hepatotoxicity}

\section{Procainamide}

Procainamide is frequently used for atrial and ventricular arrhythmias. Although rare, procainamide can cause hepatotoxicity and cases have been reported of granulomatous and intrahepatic cholestasis. Hepatotoxicity caused by procainamide is due to an unknown mechanism, but most likely it is secondary to hypersensitivity. Clinical features of hypersensitivity, including fever, rash, and nausea, are usually present. In most cases, liver 
function improves in days to weeks on discontinuation of the drug. There is only one case reported of acute pancreatitis secondary to procainamide drug-induced lupus [11]. Due to anticholinergic action, procainamide can cause constipation. The literature has only one report of a case of pseudo-obstruction in a diabetic patient with procainamide, which can happen with both oral and intravenous forms of the drug. The condition improved with the discontinuation of the drug [12].

\section{Class 1b}

Class $1 \mathrm{~b}$ drugs include lidocaine, phenytoin, mexiletine, and tocainide. Lidocaine is not reported with significant gastrointestinal side effects.

\section{Phenytoin}

Phenytoin is derived from hydantoin and is commonly used for seizure treatment. As the drug has an effect on ion channels of the cardiac membrane, it can be used as antiarrhythmic. Phenytoin is mainly metabolized and eliminated by the liver and has a narrow therapeutic window.

Phenytoin can rarely cause both acute and chronic pancreatitis. A proposed mechanism for chronic pancreatitis is the chronic induction of P450 and usually develops over years. Acute pancreatitis usually resolves with discontinuation of the drug [13].

Phenytoin is a liver enzyme inducer and can affect the metabolism of other drugs. Phenytoin can cause both acute and chronic liver damage. Liver injury can be cholestatic, cytotoxic, or mixed. Literature shows hypersensitivity is a cause of liver toxicity in over $70 \%$ cases. It can also cause irreversible liver damage associated with necrosis. A proposed mechanism is direct cytotoxic effects of toxic metabolites. Phenytoin is an aromatic antiepileptic drug and the drug metabolites cause oxidative stress, which results in hepatotoxicity [14]. There is no defined therapy, and the drug should be discontinued. Use of $\mathrm{N}$-acetylcysteine is recommended in cases with severe liver damage. Also, patients with severe hepatic damage with coagulopathy should be referred to liver transplant centers. It can worsen the hepatotoxic effects caused by acetaminophen overdose (Table 4) [15]. 


\section{Cureus}

\begin{tabular}{|c|c|c|c|c|c|}
\hline \multirow{2}{*}{ References } & \multirow{2}{*}{$\begin{array}{l}\text { Age } \\
\text { (Years)/ } \\
\text { Sex }\end{array}$} & \multirow{2}{*}{$\begin{array}{l}\text { Symptoms, signs and } \\
\text { labs }\end{array}$} & \multirow{2}{*}{$\begin{array}{l}\text { Duration } \\
\text { of Drug } \\
\text { Use }\end{array}$} & \multicolumn{2}{|l|}{ Outcome } \\
\hline & & & & & $\begin{array}{l}\text { Repeat } \\
\text { Exposure }\end{array}$ \\
\hline $\begin{array}{l}\text { Roy, et al. } \\
{[16]}\end{array}$ & 52/Female & $\begin{array}{l}\text { Elevated serum } \\
\text { aminotransferases }\end{array}$ & 11 years & $\begin{array}{l}\text { Liver biopsy showed chronic } \\
\text { persistent hepatitis. Liver functions } \\
\text { improved after discontinuation of the } \\
\text { drug. }\end{array}$ & $\begin{array}{l}\text { Etiology } \\
\text { confirmed } \\
\text { by } \\
\text { rechallenge }\end{array}$ \\
\hline $\begin{array}{l}\text { Brackett } \\
\text { and Bloch } \\
{[17]}\end{array}$ & 55/Female & Elevated liver enzymes & Unknown & $\begin{array}{l}\text { Liver enzymes improved after } \\
\text { discontinuation of acetaminophen. } \\
\text { Phenytoin predisposed } \\
\text { acetaminophen toxicity }\end{array}$ & $\begin{array}{l}\text { Phenytoin } \\
\text { continued. }\end{array}$ \\
\hline $\begin{array}{l}\text { Suchin, et } \\
\text { al. [15] }\end{array}$ & 22/Male & $\begin{array}{l}\text { Hepatic } \\
\text { encephalopathy, acute } \\
\text { renal failure, elevated } \\
\text { liver enzymes }\end{array}$ & Unknown & $\begin{array}{l}\text { Hemodialysis initiated and liver } \\
\text { transplantation done, explant showed } \\
\text { hepatic necrosis. Phenytoin worsened } \\
\text { the acetaminophen-induced } \\
\text { hepatotoxicity }\end{array}$ & Unknown \\
\hline $\begin{array}{l}\text { Altuntas, et } \\
\text { al. [18] }\end{array}$ & 47/Female & $\begin{array}{l}\text { Exfoliative dermatitis, } \\
\text { increase in liver } \\
\text { enzymes with a } \\
\text { cholestatic pattern, } \\
\text { eosinophilia }\end{array}$ & 25 days & $\begin{array}{l}\text { Liver biopsy consistent with drug- } \\
\text { induced hepatitis; liver functions } \\
\text { improved three weeks after } \\
\text { discontinuation of phenytoin }\end{array}$ & No \\
\hline
\end{tabular}

\section{TABLE 4: Comparison of Cases of Phenytoin-induced Hepatotoxicity}

\section{Mexiletine and Tocainide}

Mexiletine have has the similar structure as lidocaine and acts with the similar mechanism. At the beginning, it was used as an analgesic and is now proved effective for management of ventricular arrhythmias. Mexiletine is reported to cause esophagitis and esophageal ulcers. Cases with esophageal ulcers are treated with acid suppression. Prevention is recommended, specifically, taking the drug in the upright position with a significant amount of water [19].

Tocainide is a lidocaine analogue and has a similar electrophysiological effect. Tocainide can rarely cause hepatitis; a case with granulomatous hepatitis has been reported [20].

\section{Class 1c}

Class 1c drugs include flecainide and propafenone.

\section{Flecainide and Popafenone}

Flecainide is used for supraventricular arrhythmias as atrial fibrillation. Flecainide rarely causes gastrointestinal side effects. A case of hepatitis caused by flecainide has been reported. The assumed mechanism of hepatotoxicity was an allergic reaction, and the liver enzymes improved after withdrawal of drug [21]. 
Propafenone has a beta blocker effect and can cause bradycardia. It is primarily metabolized by the liver. There are a handful of cases of propafenone-induced hepatotoxicity; toxicity can be hepatocellular or cholestatic. Liver functions improve with discontinuation of the drug [22].

\section{Class 2}

Class 2 drugs include beta blockers, such as propranolol, metoprolol, atenolol, esmolol, and acebutolol.

\section{Beta-adrenergic Receptor Blockers}

Beta blockers are commonly used for hypertension, arrhythmias, migraine, glaucoma, and anxiety. Beta blockers decrease mortality in patients with atrial fibrillation with or without heart failure. Selective beta-adrenergic blockers are used for atrial and ventricular arrhythmias. Beta blockers have a wide therapeutic index but their use is associated with various side effects.

Although very rare, atenolol, carvedilol, and metoprolol can cause hepatotoxicity as evident in case reports but the etiology is unknown. Atenolol-associated hepatotoxicity is observed in very few cases, liver biopsy shows inflammatory infiltrate suggestive of immune-mediated process and cases improved with discontinuation of the drug (Table 5) [23]. The study by Packer, et al. showed that $0.3 \%$ of patients of carvedilol developed abnormal liver functions leading to discontinuation of drug [24]. There is only one case of metoprolol-induced hepatotoxicity. A proposed mechanism was poor oxidation of the drugs debrisoquine and perhexiline [25]. 


\section{Cureus}

\begin{tabular}{|c|c|c|c|c|c|}
\hline \multirow{2}{*}{ Reference } & \multirow{2}{*}{ Drug } & \multirow{2}{*}{$\begin{array}{l}\text { Age } \\
\text { (Years)/ } \\
\text { Sex }\end{array}$} & \multirow{2}{*}{$\begin{array}{l}\text { Symptoms, } \\
\text { signs and } \\
\text { labs }\end{array}$} & \multicolumn{2}{|l|}{ Outcome } \\
\hline & & & & & $\begin{array}{l}\text { Repeat } \\
\text { Exposure }\end{array}$ \\
\hline $\begin{array}{l}\text { Kootte, et } \\
\text { al. [26] }\end{array}$ & Sotalol & 68/Female & $\begin{array}{l}\text { Elevated Liver } \\
\text { enzymes }\end{array}$ & $\begin{array}{l}\text { Liver functions Normalized in five months } \\
\text { after discontinuation of the drug. }\end{array}$ & Unknown \\
\hline $\begin{array}{l}\text { Hagmeyer } \\
\text { and Stein } \\
{[27]}\end{array}$ & Carvedilol & 40/Male & $\begin{array}{l}\text { Pruritis, } \\
\text { elevated } \\
\text { serum } \\
\text { transaminases }\end{array}$ & $\begin{array}{l}\text { Carvedilol was discontinued, symptoms } \\
\text { improved with hydroxyzine. The drug was } \\
\text { discontinued and liver enzymes improved } \\
\text { after three weeks. }\end{array}$ & $\begin{array}{l}\text { One year later, } \\
\text { the patient was } \\
\text { started on } \\
\text { metoprolol and } \\
\text { developed } \\
\text { pruritus in } 10 \\
\text { days and the } \\
\text { drug was } \\
\text { stopped. Liver } \\
\text { enzymes } \\
\text { remained } \\
\text { normal. }\end{array}$ \\
\hline $\begin{array}{l}\text { Dumortier, } \\
\text { et al. [23] }\end{array}$ & Atenolol & 57/Female & $\begin{array}{l}\text { Asthenia and } \\
\text { elevated liver } \\
\text { enzymes }\end{array}$ & $\begin{array}{l}\text { Liver biopsy showed portal and } \\
\text { centrilobular inflammation. After receiving } \\
\text { steroids, liver function tests improved but } \\
\text { were still elevated; repeat biopsy showed } \\
\text { necrosis in centrilobular areas with } \\
\text { pigmented macrophages. Liver function } \\
\text { tests normalized two months after } \\
\text { discontinuation of atenolol. Control liver } \\
\text { biopsy in seven months showed } \\
\text { disappearance of centrilobular lesions. }\end{array}$ & No \\
\hline
\end{tabular}

TABLE 5: Comparison of beta blocker hepatotoxicity cases

Propranolol can be a risk factor for ischemic colitis if a patient is on multiple antihypertensive medications. There is a case where the patient was on nicardipine hydrochloride, propranolol hydrochloride, and digoxin for hypertension; she developed ischemic colitis post-colonoscopy and clinically improved with conservative management [28].

\section{Class 3}

Class 3 drugs include amiodarone, sotalol, dronedarone, and dofetilide.

Amiodarone

Amiodarone has a similar structure as thyroid hormone. It is a lipophilic drug and can deposit in fat tissues and liver. It is metabolized slowly, so its effects take longer to resolve. As discussed earlier, amiodarone has multiple class actions. Long-term use can cause extracardiac adverse effects as pulmonary toxicity, thyroid dysfunction, corneal deposits, and liver toxicity [29]. 


\section{Cureus}

Hepatotoxicity ranges from asymptomatic elevated transaminases (25\%) to severe liver damage (1\% - 3\%). Asymptomatic abnormal liver function tests (LFT) usually resolve with dose reduction or stopping the drug. Liver toxicity has been observed with both oral and IV drugs. The mechanism of liver damage with amiodarone is unclear. It could be immunemediated hepatocyte damage with free radical formation. Damage secondary to parenteral amiodarone may be due to solvent Polysorbate 80 . Polysorbate 80 is short-acting and liver function improves quickly after discontinuation of parenteral amiodarone [29]. In patients where hepatotoxicity due to amiodarone infusion is seen, oral amiodarone is safe to continue (Table 6). The North American Society of Pacing and Electrophysiology (NASPE) recommends the monitoring of LFT every six months after a baseline check at the time of starting the amiodarone [30].

\section{References} (Years)/ Sex

79/Male

Singhal, et

al. [31]

Coffee ground emesis, lethargy, ascites,

spider nevi, gynecomastia, palmar erythema

Liver function

Rizzioli, et

al. [32]

79/Female

ests increased acutely

after the start of amiodarone infusion

Kang, et al. [33]

75/Male polyneuropathy for three months and mildly elevated liver enzymes

Significantly elevated

Lahbabi, et

al. [34]

29/Female enzymes acutely after starting amiodarone infusion

Significantly elevated liver enzymes after

Fonesca, et al. [29] start of amiodarone infusion with thrombocytopenia and acute kidney injury

\section{Outcome}

Duration

\section{Repeat}

Exposure

Cirrhosis and extensive fibrosis confirmed on liver biopsy. Amiodarone was discontinued. months The patient developed renal No failure, heart failure, hepatic encephalopathy and died in three months.

Amiodarone infusion was stopped, transaminases started

One day to decrease. Progressive No congestive heart failure led to death on same admission.

Liver biopsy showed microvesicular steatosis, foam cells, and Mallory bodies.

17.8 months

Amiodarone was discontinued; liver enzymes improved on day three and symptoms slowly improved.

Amiodarone infusion was stopped and replaced by oral amiodarone. Liver functions improved gradually.

24 hours

Amiodarone infusion was

18 hours stopped; liver and renal functions gradually normalized.
Oral amiodarone continued; liver function tests after two months were normal

Oral amiodarone was restarted on day four at lower dose and liver functions were normal on followup 


\section{Cureus}

Chen and

Wu [35]
Acutely elevated liver

Unknown enzymes after starting

amiodarone infusion
Amiodarone infusion was

stopped; liver enzymes

normalized.
Oral amiodarone

was started on lower dose and hepatotoxicity did not occur on follow-up

TABLE 6: Comparison of a Few Case Reports of Amiodarone-induced Hepatitis in the Literature

A large retrospective cohort study conducted in Taiwan showed that use of amiodarone is associated with malignant neoplasm of the liver and intrahepatic bile ducts (MNLIHD) in a dose-dependent manner. Malignancy is common in cases with comorbidities, such as diabetes, chronic liver disease, cirrhosis, hepatitis C, hepatitis B, and alcoholism (Table 7) [36].

\begin{tabular}{ll} 
Medications & MNLIHD odds rat \\
\hline Amiodarone & $1.6(1.45-1.77)$ \\
\hline Mexiletine & $1.07(0.98-1.18)$ \\
\hline Propafenone & $0.97(0.85-1.11)$ \\
\hline Quinidine & $1.32(0.91-1.93)$ \\
\hline Procainamide & $0.97(0.71-1.33)$
\end{tabular}

TABLE 7: Odds Ratio with Confidence Interval of $95 \%$ for Malignant Neoplasm of the Liver and Intrahepatic Bile Ducts (MNLIHD) Associated with Amiodarone and Other Antiarrhythmics

Modified from Yun-Ping, et al. [36]

Amiodarone can rarely cause acute pancreatitis as there are few case reports in the literature. A case control population study by Lai, et al. showed the current use of amiodarone increases the risk of acute pancreatitis (Table 8) [37]. The exact mechanism of pancreatitis caused by amiodarone is unknown. Proposed mechanisms are direct toxicity caused by amiodarone and its metabolite, mono-N-desethylamiodarone, due to its lipophilic nature. Amiodarone is metabolized by $\mathrm{P} 450$, and pancreatitis can be caused by drug-drug interaction. The case reports show improvement of pancreatitis symptoms with discontinuation of the drug (Table 9). 


\section{Cureus}

\begin{tabular}{l|l}
\hline Amiodarone use & Acute pancreatiti \\
\hline Current Use & $5.21(3.22-8.43)$ \\
\hline Recent Use & $1.18(0.32-4.35)$ \\
\hline Past Use & $1.42(0.99-2.03)$
\end{tabular}

\section{TABLE 8: Amiodarone-associated Acute Pancreatitis}

Modified from Lai, et al. [37]

\begin{tabular}{|l|l|l|l|l|}
\hline References & $\begin{array}{l}\text { Age } \\
\text { (Years)/ }\end{array}$ & $\begin{array}{l}\text { Symptoms, } \\
\text { signs and } \\
\text { Sex }\end{array}$ & Duration & \\
\hline & labs & \\
\hline
\end{tabular}

Bosch and

Bernadich 46/Female

[38]

Famularo,

et al. [39]

80/Male$$
\text { vomiting, }
$$

Epigastric

pain,

distended

abdomen,

elevated

amylase,

and lipase

Epigastic

pain, loss

Chen, et al.

[40]

66/Female

and

elevated

lipase

Intravenous fluids were given; symptoms resolved after discontinuation of the drug. Procainamide was started.

Amiodarone dose was reduced to $200 \mathrm{mg}$ daily from loading dose; symptoms and serum lipase levels improved after three days.

Abdominal pain persisted even after three weeks of conservative management. All causes ruled out.

Amiodarone was substituted No with propafenone; symptoms resolved and lipase gradually trended down

\section{Repeat Exposure}

Procainamide was stopped and amiodarone was started at low dose $100 \mathrm{mg}$ per day. After three days, the patient had recurrence of symptoms with elevated amylase and lipase. Amiodarone was stopped and procainamide was restarted.

Rechallenge with a high dose of amiodarone was not performed and continued with 200 mg.

TABLE 9: Summary and Comparison of Cases of Amiodarone-induced Pancreatitis 


\section{Cureus}

\section{Sotalol}

Sotalol is a non-selective beta blocker and can be used for the treatment of atrial fibrillation, ventricular tachycardia, premature ventricular contractions, and supraventricular tachycardia. Sotalol is a hydrophilic drug and not metabolized by the liver; still, one case of severe chronic hepatitis has been reported. The mechanism of liver injury is unknown. Patient symptoms improved and liver functions normalized on discontinuation of the drug (Table 5) [26].

\section{Dronedarone}

Dronedarone is a newer drug and has a structure similar to amiodarone. The drug is used for atrial fibrillation and atrial flutter. Dronedarone can cause hepatotoxicity with mitochondrial damage. A study on rat liver cells explained the mechanism, as it inhibited the electron transport chain and beta oxidation; this caused increased production of reactive oxygen species (ROS), which led to apoptosis and mitochondrial damage [41]. There are a few cases of severe toxic hepatitis. Two of the hepatic failure cases were treated with the emergent liver transplant (Table 10) [42].

\begin{tabular}{|c|c|c|c|c|c|}
\hline \multirow{2}{*}{ Reference } & \multirow{2}{*}{$\begin{array}{l}\text { Age } \\
\text { (Years)/ } \\
\text { Sex }\end{array}$} & \multirow{2}{*}{$\begin{array}{l}\text { Symptoms, Signs } \\
\text { and Labs }\end{array}$} & \multirow{2}{*}{ Duration } & \multicolumn{2}{|l|}{ Outcome } \\
\hline & & & & & $\begin{array}{l}\text { Repeat } \\
\text { Exposure }\end{array}$ \\
\hline $\begin{array}{l}\text { Rel Pozo } \\
\text { Ruis, et al. }\end{array}$ & 75/Male & $\begin{array}{l}\text { Nausea, vomiting, } \\
\text { abdominal pain, } \\
\text { elevated liver } \\
\text { enzymes }\end{array}$ & $\begin{array}{l}\text { Four } \\
\text { days }\end{array}$ & $\begin{array}{l}\text { Patient developed fulminant liver tallure, } \\
\text { dronedarone was discontinued. Liver } \\
\text { functions improved after seven days of } \\
\text { discontinuation and ICU monitoring }\end{array}$ & No \\
\hline $\begin{array}{l}\text { Jahn, et } \\
\text { al. [42] }\end{array}$ & 69/Female & $\begin{array}{l}\text { Elevated liver } \\
\text { enzymes }\end{array}$ & Unknown & $\begin{array}{l}\text { Acute liver failure resolved after } \\
\text { discontinuation of the drug. }\end{array}$ & Unknown \\
\hline $\begin{array}{l}\text { Rizkallah, } \\
\text { et al. [44] }\end{array}$ & 85/Male & $\begin{array}{l}\text { Nausea and } \\
\text { elevated liver } \\
\text { enzymes }\end{array}$ & One day & $\begin{array}{l}\text { Drug was discontinued after three doses; the } \\
\text { patient developed multiorgan failure and died } \\
\text { on day } 8 .\end{array}$ & No \\
\hline
\end{tabular}

\section{TABLE 10: Summary of Cases of Dronedarone-induced Hepatotoxicity}

ICU: intensive care unit

\section{Class 4}

Class 4 drugs include calcium channel blockers (CCB), such as verapamil and diltiazem.

Verapamil

Verapamil is commonly used for supraventricular tachycardia, hypertension, and angina. Verapamil not only acts on the calcium channel in the heart muscle but also on vascular and gastrointestinal smooth muscle. The most common adverse effect of verapamil is constipation ranging from $6-8 \%$. The mechanism is likely slow transit time in the colon and less likely upper gastrointestinal tract. Constipation is sometimes significant enough to discontinue the drug. 
Verapamil was also reported to aggravate a pseudo-obstruction in a case report, which improved once verapamil was discontinued [45].

A prospective cohort study showed that CCBs used for hypertension, including verapamil and diltiazem, increased the risk of gastrointestinal hemorrhage in the elderly population. Therefore, CCBs need to be used with caution in an elderly population with risks of gastrointestinal hemorrhage [46]. Rarely, verapamil can lead to idiosyncratic hepatitis. Symptoms and liver functions improve with discontinuation of drug [47].

\section{Diltiazem}

Diltiazem is commonly used for supraventricular tachycardia, hypertension, and angina. The drug has an extensive first-pass hepatic metabolism. CCBs are a weak inhibitor of CYP 3A4 and increase serum levels of medications metabolized by CYP 3A4. Intravenous infusion of diltiazem can drop the blood pressure and can lead to hypoxic liver injury. There was a case of hypoxic hepatitis in a patient who was started on diltiazem for atrial fibrillation. Liver congestion due to heart failure can also be a contributing factor. In this case of hypoxic hepatitis, the diltiazem infusion was stopped; anticoagulation was held initially because of liver toxicity-induced coagulopathy [48].

A case of paralytic ileus was reported in a patient taking diltiazem for atrial fibrillation and rapidly improved after discontinuation of the drug. The proposed mechanism was decreased gastrointestinal motility due to inhibition of calcium channels in GI smooth muscles [49].

\section{Digoxin}

Digoxin is one of most commonly used antiarrhythmics. It is also used in patients with atrial fibrillation and heart failure. Digoxin can cause nonspecific gastrointestinal side effects, such as nausea and vomiting.

A case control study by Lai, et al. showed an increased odds ratio of acute pancreatitis in patients with active digoxin use, and risk was further increased in a patient with chronic kidney disease as 70\% of digoxin is normally excreted from the kidneys. The Food and Drug Administration (FDA) has reported 0.2\% of cases of acute pancreatitis from 1997 to 2012 in patients on digoxin. The exact pathophysiology was not known; it could have been due to a drug-drug interaction. The proposed mechanism was that digoxin causes hypomagnesemia, which leads to increased glycosaminoglycan levels in the pancreas and can lead to pancreatitis [50].

Adenosine

Adenosine is a natural nucleoside, is given as an intravenous infusion, and has a very short half-life. It is used for the treatment of paroxysmal supraventricular tachycardia. Because of its short half-life, adenosine is not associated with any major adverse effects.

\section{Conclusions}

In conclusion, the gastrointestinal side effects of anti-arrhythmic drugs could lead to discontinuation of these medications in several appropriately treated patients. Knowledge of these side effects could help in identifying these side effects and appropriate drug therapy in patients with arrhythmia. 


\section{Additional Information \\ Disclosures}

Conflicts of interest: In compliance with the ICMJE uniform disclosure form, all authors declare the following: Payment/services info: All authors have declared that no financial support was received from any organization for the submitted work. Financial relationships: All authors have declared that they have no financial relationships at present or within the previous three years with any organizations that might have an interest in the submitted work. Other relationships: All authors have declared that there are no other relationships or activities that could appear to have influenced the submitted work.

\section{References}

1. Kowey PR: Pharmacological effects of antiarrhythmic drugs. Review and update. Arch Intern Med. 1998, 158:325-32. 10.1001/archinte.158.4.325

2. Bramlet DA, Posalaky Z, Olson R: Granulomatous hepatitis as a manifestation of quinidine hypersensitivity. Arch Intern Med. 1980, 140:395-97. 10.1001/archinte.1980.00330150109025

3. Guharoy SR, Shahin J, Levin S: Quinidine-induced hepatotoxicity revisited. Vet Hum Toxicol. 1991, 33:613-14.

4. Handler SD, Hirsch NR, Haas K, et al.: Quinidine hepatitis. Arch Intern Med. 1975, 135:871-72. 10.1001/archinte.1975.00330060115018

5. Hogan DB, Morin J, Crilly RG: Unusual hepatotoxic reaction to quinidine. Can Med Assoc J. 1984, 130:973.

6. Zografos GN, Georgiadou D, Thomas D, et al.: Drug-induced esophagitis. Dis Esophagus. 2009, 22:633-37. 10.1111/j.1442-2050.2009.00972.x

7. Rinard J, Rodriguez S, Ormseth E: Quinidine-induced gastric ulcer. Gastrointest Endosc. 2004, 60:481-83. 10.1016/S0016-5107(04)01716-X

8. Scheinman SJ, Poll DS, Wolfson S: Acute cardiac failure and hepatic ischemia induced by disopyramide phosphate. Yale J Biol Med. 1980, 53:361-66.

9. Bakris GL, Cross PD, Hammarsten JE: Disopyramide-associated liver dysfunction. Mayo Clin Proc. 1983, 58:265-67.

10. Doody PT: Disopyramide hepatotoxicity and disseminated intravascular coagulation. South Med J. 1982, 75:496-98.

11. Falko JM, Thomas FB: Acute pancreatitis due to procainamide-induced lupus erythematosus . Ann Intern Med. 1975, 83:832-33. 10.7326/0003-4819-83-6-832

12. Peterson AM, Conrad SD, Bell JM: Procainamide-induced pseudo-obstruction in a diabetic patient. DICP. 1991, 25:1334-35.

13. Sepúlveda Vildósola AC, López Aguilar E, Yáñez López P, et al.: Sodium diphenylhydantoin as a probable cause of pancreatitis (Article in Spanish). Rev Gastroenterol Mex. 1999, 64:186-89.

14. Santos NAG, Medina WSG, Martins NM, et al.: Involvement of oxidative stress in the hepatotoxicity induced by aromatic antiepileptic drugs. Toxicol In Vitro. 2008, 22:1820-24. 10.1016/j.tiv.2008.08.004

15. Suchin SM, Wolf DC, Lee Y, et al.: Potentiation of acetaminophen hepatotoxicity by phenytoin, leading to liver transplantation. Dig Dis Sci. 2005, 50:1836-38. 10.1007/s10620005-2947-4

16. Roy AK, Mahoney HC, Levine RA: Phenytoin-induced chronic hepatitis. Dig Dis Sci. 1993, 38:740-43.

17. Brackett CC, Bloch JD: Phenytoin as a possible cause of acetaminophen hepatotoxicity: case report and review of the literature. Pharmacotherapy. 2000, 20:229-33.

10.1592/phco.20.3.229.34774

18. Altuntaş Y, Oztürk B, Erdem L, et al.: Phenytoin-induced toxic cholestatic hepatitis in a patient with skin lesions: case report. South Med J. 2003, 96:201-3.

10.1097/01.SMJ.0000051269.23361.4A

19. Penalba C: Esophageal ulcerations induced by mexiletine hydrochloride (Article in French) . Ann Gastroenterol Hepatol (Paris). 1986, 22:267-68.

20. Tucker LE: Tocainide-induced granulomatous hepatitis. JAMA. 1986, 255:3362. 
21. Kühlkamp V, Haasis R, Seipel L: Flecainide-induced hepatitis (Article in German) . Z Kardiol. 1988, 77:678-80.

22. Younan LB, Barada KA, Faraj WG, et al.: Propafenone hepatotoxicity: Report of a new case and review of the literature. Saudi J Gastroenterol. 2013, 19:235-37. 10.4103/13193767.118137

23. Dumortier J, Guillaud O, Gouraud A, et al.: Atenolol hepatotoxicity: Report of a complicated case. Ann Pharmacother. 2009, 43:1719-23. 10.1345/aph.1M247

24. Packer M, Bristow MR, Cohn JN, et al.: The effect of carvedilol on morbidity and mortality in patients with chronic heart failure. N Engl J Med. 1996, 334:1349-55.

10.1056/NEJM199605233342101

25. Lennard MS: Metoprolol-induced hepatitis: is the rate of oxidation related to drug-induced hepatotoxicity?. Hepatology. 1989, 9:163-64. 10.1002/hep.1840090126

26. Kootte AM, Janssens AR, Ouwehand DK, van Leeuwen AM: Chronic hepatitis ascribed to the use of sotalol (Article in Dutch). Ned Tijdschr Geneeskd. 2001, 145:2340-43.

27. Hagmeyer KO, Stein J: Hepatotoxicity associated with carvedilol . Ann Pharmacother. 2001, 35:1364-66. 10.1345/aph.10239

28. Nozawa H, Akiyama Y, Sunaga S, Tsurita G: Ischemic colitis following colonoscopy in an elderly patient on cardiovascular medication. Endoscopy. 2007, 39:E344-45. Accessed: 10.1055/s-2007-995329: http://www.thieme-connect.de/products/ejournals/pdf/10.1055/s2007-995329.pdf.

29. Fonseca P, Dias A, Gonçalves H, et al.: Acute hepatitis after amiodarone infusion. World J Clin Cases. 2015, 3:900-903. 10.12998/wjcc.v3.i10.900

30. Bickford CL, Spencer AP: Adherence to the NASPE guideline for amiodarone monitoring at a medical university. J Manag Care Pharm. 2006, 12:254-59. 10.18553/jmcp.2006.12.3.254

31. Singhal A, Ghosh P, Khan SA: Low dose amiodarone causing pseudo-alcoholic cirrhosis. Age Ageing. 2003, 32:224-5. 10.1093/ageing/32.2.224

32. Rizzioli E, Incasa E, Gamberini S, et al.: Acute toxic hepatitis after amiodarone intravenous loading. Am J Emerg Med. 2007, 25:1082.e1-4. 10.1016/j.ajem.2007.02.045

33. Kang HM, Kang YS, Kim SH, et al.: Amiodarone-induced hepatitis and polyneuropathy. Korean J Intern Med. 2007, 3:225-29. 10.3904/kjim.2007.22.3.225

34. Lahbabi M, Aqodad N, Ibrahimi A, et al.: Acute hepatitis secondary to parenteral amiodarone does not preclude subsequent oral therapy. World J Hepatol. 2012, 4:196-98. 10.4254/wjh.v4.i6.196

35. Chen CC, Wu CC: Acute hepatotoxicity of intravenous amiodarone: Case report and review of the literature. Am J Ther. 2016, 23:e260-63. 10.1097/MJT.0000000000000149

36. Lim YP, Lin CL, Lin YN, et al.: Antiarrhythmic agents and the risk of malignant neoplasm of liver and intrahepatic bile ducts. PloS One. 2015, 10:e0116960. 10.1371/journal.pone.0116960

37. Lai SW, Lin CL, Liao KF, Lin CY: Amiodarone use and risk of acute pancreatitis: A populationbased case-control study. Heart Rhythm. 2015, 12:163-66. 10.1016/j.hrthm.2014.08.037

38. Bosch X, Bernadich O: Acute pancreatitis during treatment with amiodarone. Lancet. 1997, 350:1300. 10.1016/S0140-6736(05)62478-6

39. Famularo G, Minisola G, Nicotra GC, et al.: Acute pancreatitis caused by amiodarone. Eur J Emerg Med. 2004, 11:305-306. 10.1097/00063110-200410000-00015

40. Chen YY, Chen CY, Leung KK: Acute pancreatitis and amiodarone: A case report. World J Gastroenterol. 2007, 13:975-77.

41. Felser A, Blum K, Lindinger PW, et al.: Mechanisms of hepatocellular toxicity associated with dronedarone - A comparison to amiodarone. Toxicol Sci. 2013, 131:480-90. 10.1093/toxsci/kfs298

42. Jahn S, Zollner G, Lackner C, Stauber RE: Severe toxic hepatitis associated with dronedarone. Curr Drug Saf. 2013, 8:201-202. 10.2174/15748863113089990031

43. Del Pozo Ruiz JJ, Martin Sanz A, Alvarez Vicente G, et al.: Dronedarone-associated hepatotoxicity. A propos of a case (Article in Spanish). Farm Hosp. 2012, 36:545-47 . 10.7399/FH.2012.36.6.48

44. Rizkallah J, Kuriachan V, Brent Mitchell L: The use of dronedarone for recurrent ventricular tachycardia: a case report and review of the literature. BMC Res Notes. 2016, 9:370. 10.1186/s13104-016-2116-1

45. Schultz HS, Vernon B: Intestinal pseudo-obstruction related to using verapamil . West J Med. 


\section{Cureus}

1989, 151:556-8.

46. Pahor M, Guralnik JM, Furberg CD, et al.: Risk of gastrointestinal haemorrhage with calcium antagonists in hypertensive persons over 67 years old. Lancet. 1996, 347:1061-65.

10.1016/S0140-6736(96)90276-7

47. Odeh M, Oliven A: Verapamil-associated liver injury (Article in Hebrew). Harefuah. 1998, 134:36-37.

48. Deng W, Farricielli L: Hypoxic hepatitis and acute liver failure in a patient with newly onset atrial fibrillation and diltiazem infusion. BMJ. 2013, 2013:pii: bcr2013200573. 10.1136/bcr2013-200573

49. Wright S, Ali M, Robinson A, et al.: Paralytic ileus associated with use of diltiazem . Am J Health Syst Pharm. 2011, 68:1426-29. 10.2146/ajhp100582

50. Lai SW, Lin CL, Liao KF: Digoxin use may increase the relative risk of acute pancreatitis: A population-based case-control study in Taiwan. Int J Cardiol. 2015, 181:235-38.

10.1016/j.ijcard.2014.11.217 